\title{
A rede de apoio no tratamento oncológico
}

Luciana Geyer Kopelman Thalenberg ${ }^{1}$

\section{Apresentação}

A seguir apresentamos o relato de uma experiência ímpar de luta pela vida, em que a formação de uma rede de ajuda, de apoio, de troca, de amizade foi fundamental.

Luciana Kopelman Thalenberg (1965-2009) é a protagonista desta história de vida. Ela, com sua alegria, humor, generosidade, sensibilidade e inteligência teceu, com suas amigas, uma rede para ajudá-la a lutar contra um câncer de mama e para sustentar sua vitalidade e das pessoas ao seu redor. Ela amava a vida e a enfrentou com a maior garra e dignidade. Qual sua maior força? Seu amor, sua potência afetiva.

Era seu desejo tornar público seu texto-testemunho, uma pequena amostra de sua generosidade. Ela queria revelar para as pessoas, sobretudo aquelas que enfrentam situações tão difíceis como a que enfrentou, que há um caminho possível e vital em meio à mata densa de uma doença grave. Ela ensinou-nos que, mesmo diante de uma doença terrível, podemos nos manter ativos e vivos.

O relato em terceira pessoa é uma maneira de a autora se preservar, tomar distância do que the acontecia para colocar em andamento um processamento importante para ela e para outros. Nada faz um escrito mais valioso do que usálo como um instrumento para encontrar meios de tornar a vida possível e digna. Segue esse texto-tesouro.

Paula Patrícia Francisquetti, médica psiquiatra, psicanalista e membro do Departamento de Psicanálise do Instituto Sedes Sapientiae. Esta Apresentação foi escrita com base em alguns encontros com membros da rede de apoio descrita no texto "A rede de apoio no tratamento oncológico", em janeiro e fevereiro de 2010.ppsnf@uol.com.br 
O termo "rede" vem sendo utilizado comumente na área de saúde. Esta terminologia, cujo significado é amplo e, portanto, pouco preciso, não deixa de ter um valor fundamental enquanto ideia que permite a construção efetiva de um aparato que favorece certos tratamentos ${ }^{2}$.

No campo da saúde mental, por exemplo, a noção de rede envolve a utilização de uma equipe multidisciplinar que favorece uma visão do paciente em suas diversas facetas. Atualmente, fala-se de múltiplas redes existentes na internet, inclusive para apoio às pessoas doentes. Pois bem, não é deste tipo de rede que pretendo falar. A minha ideia é discutir a importância de um grupo muito específico, fundamental para o paciente em tratamento oncológico, qual seja: o grupo de pessoas que o acompanha durante o tratamento.

Comumente, a resolução de quem estará presente nas aplicações de quimioterapia ou de radioterapia, nas consultas médicas, exames, e tudo o mais que for necessário, é tomada num momento em que tanto o doente quanto os seus próximos estão ainda sob o efeito desorganizador da constatação da doença. Assim como em nosso cotidiano estamos sempre fazendo projetos, no adoecimento também se faz necessário um projeto de tratamento.

É inegável que uma doença desta ordem seja um atravessamento em nossas vidas. Ela se impõe, e, assim, nos impõe uma nova tarefa: dar o devido tamanho a ela. Com isso afirmo que é possível não ser a doença, mas ter a doença.

É uma conquista muito recente poder nomear esta moléstia. Há apenas algumas décadas usavam-se expressões do tipo: "Ele está com aquela coisa ruim", "É aquilo que não pode falar", e outras mais. A consequência imediata desta impossibilidade de nomeação é a permanência, na fantasia, de uma série de ideias a respeito do adoecimento que não podem ser compartilhadas, seja com o médico ou qualquer outra pessoa. Muitas destas fantasias nem sempre encontram respaldo na realidade. Por exemplo: o câncer, cada vez mais, está deixando de ser uma sentença de morte.

Quanto ao caráter punitivo que, muitas vezes, a ela está associado, imaginariamente, afirmo que não há sujeito algum tão onipotente que possa causar a si mesmo o câncer. Se assim fosse, o trabalho do psicólogo seria na linha de demover o sujeito desta ideia absurda de adoecer. Apesar de não ser de sua responsabilidade o seu adoecimento, é tarefa de cada doente trabalhar a favor do tratamento.

Susan Sontag (2007), buscando desmistificar certas doenças, como a tuberculose, o câncer e a aids, traz uma importante contribuição relativa ao imaginário das pessoas acometidas por estas patologias. A autora afirma que quanto menos conhecidos são os mecanismos das doenças em sua totalidade, mais o imaginário toma conta de explicá-las e, quando o faz, sempre surgem respostas de cunho moral, religioso ou, até mesmo, ideológico.

Retomando a ideia de que o câncer pode ser explicado como uma forma de punição, de expiação de culpa, o filósofo e religioso Martin Buber (1979), ao abordar a temática da relação do homem com Deus, lembra que dívidas entre os homens só podem ser "quitadas" entre os mesmos. Não cabe mais pensar a doença ou, até mesmo, a morte como um último gesto de nobreza. Nada disso impede que o paciente encontre apoio na religião.

Voltando à ideia de que é necessário que se faça um planejamento para o tratamento, tenho experimentado, na clínica, que isto é um processo e pode haver mudanças a partir da experiência. De qualquer maneira, não cabem automatismos. O paciente precisa ser ouvido. Ele pode e deve tomar decisões.

A empatia com o sofrimento do outro, muitas vezes, acaba se convertendo numa atitude de poupar ao máximo quem está doente, evitando até que ele se ocupe de si mesmo. Ao ser humano não é dado o direito de tirar férias de si mesmo. Então, mãos à obra!
${ }^{2}$ Para uma discussão geral sobre o conceito de rede social e sua utilização na área de saúde, ver Sluzki (1997). 
É preciso levar em conta que este sofrimento se estende às outras pessoas, tais como:

companheiros, familiares e amigos. É justamente neste ponto que a noção de rede toma sentido. Sua construção tem dupla finalidade. Ela tanto tem de servir de suporte para o paciente como precisa se autossustentar. Darei, como exemplo, o de uma rede em funcionamento que atingiu a sua dupla finalidade. Trata-se de um grupo constituído em novembro de 2007 e que ainda segue funcionando.

Num primeiro momento foram listadas tanto as necessidades da paciente, que iam muito além das sessões de quimioterapia, bem como as disponibilidades dos familiares e amigos. As disponibilidades foram apresentadas à paciente que, por sua vez, decidiu o que lhe parecia o principal: quem ela gostaria de ter junto a si nas aplicações de quimioterapia.

Esta organização trouxe uma tranquilidade a todos. De início, por meio de e-mails, a dupla escalada para a aplicação tinha o dever de mandar notícias relativas ao estado da paciente. Este era o foco. Com o tempo, estes e-mails passaram a conter comunicações relativas às vivências dos acompanhantes. Foi justamente a partir deste ponto que a rede passou a cumprir a sua outra função: a de autossustentação, que nada mais é do que um amparo mútuo.

A esta rede foram sendo incorporadas mais pessoas, que ajudavam, inclusive, em outras funções, tais como: compras, leva e traz dos filhos e sessões de DVD, muitas vezes acompanhadas de pipoca e pessoas, grupos de rezas e, até, um grupo autointitulado de grupo dos "bolinhas" (amigos do marido da paciente), com encontros mensais para jogar conversa fora - ou dentro?

Em relação às redes que tenho acompanhado, percebo que quanto maior é a capacidade de comunicação entre seus membros, mais ela se torna flexível e eficiente. O bom funcionamento destas redes tem consequências importantes para todo o tratamento, ou, dito de outra forma, ela é facilitadora do trabalho dos médicos bem como o da enfermagem.

Conforme o impacto inicial da constatação da doença é elaborado, as pessoas envolvidas no tratamento vão sendo reconhecidas em sua importância. Isso exige tempo e, portanto, é da ordem da construção.

Uma experiência desta ordem pode não significar somente dor. Como toda crise, ela também oferece a possibilidade do aumento do patrimônio emocional, de se criarem novas oportunidades. Apesar de o linguajar muitas vezes ser o mesmo dos quartéis: "vamos vencer mais esta batalha", "venceremos o inimigo", "ainda temos muita munição", e assim por diante, prefiro ficar com a imagem do junco que precisa vergar-se para não quebrar. A flexibilidade é característica fundamental dos movimentos criativos. É possível que esta seja uma das maiores exigências desta doença: ser criativo, ousar, fazer projetos prazerosos para além da doença.

\section{Referências}

BUBER, M. Eu e tu. São Paulo: Cortez e Moraes, 1979.

SLUZKI, C.E. A rede social na prática sistêmica. São Paulo: Casa do Psicólogo, 1997.

SONTAG, S. Doença como metáfora: AIDS e suas metáforas. São Paulo: Companhia das Letras, 2007. 